\title{
I THINK I CAN, I KNOW I CAN? SUCCESS ORIENTATION IN ADULT LEARNER ACADEMIC SELF-DIRECTEDNESS
}

\author{
J. Botha \\ Department of Human Resource Management \\ University of South Africa \\ Pretoria, South Africa \\ e-mail: bothaj1@unisa.ac.za / https://orcid.org/0000-0003-3718-2269
}

\section{ABSTRACT}

A Learning 2.0 milieu requires an active learner mindset, where the learner initiates and directs the learning experience. Consequently, adult learner academic self-directedness is essential for facilitating successful lifelong learning. Learner self-directedness is of specific importance in South African higher education, since only about 12 per cent of qualifying matriculants will continue to higher education, and of those, only about 6 per cent will qualify within 6 years. Adult learner selfdirectedness broadly consists of contextual (learning environment), cognitive (agency) and behavioural (self-management) elements. Although researchers agree that a fairly well-developed capacity for self-directedness is a requirement for successful ODeL studies, there is a lack of research on adult learner self-directedness in the South African ODeL context. The adult learner self-directedness scale (ALSDS) was developed to investigate adult learners in an ODeL context. The scale produced four factors describing adult learner self-directedness in, of which success orientation seems to be the most noteworthy.

Keywords: adult learner, self-directedness, success orientation, ODeL, South Africa

\section{INTRODUCTION}

Learning 2.0 milieu requires autonomous learners who actively direct their personal learning journey through social media, communities of expert practice and personal learning networks. Consequently, the capacity for self-directedness is advantageous for successfully implementing lifelong learning (Beach 2017, 61; Wang et al. 2008, 18). Learner self-directedness is of specific importance in South African higher education, since only about 12 per cent of qualifying matriculants will continue to higher education, and of those, only about 6 per cent will qualify within 6 years (Van Broekhuizen, Van Der Berg, and Hofmeyr 2016, ii). Clearly, the uptake of higher education in South Africa is low, and the success or throughput rate of registered students is even lower. According to 2017 information, 1360984 students enrolled for public higher education (PHE), a rise of almost 200000 students between 2009 and 2017 (Department of Higher Education and Training (DHET) 2017, 10). Distance education accounted for 36 per cent of enrolments in 2017 (DHET 2017, 9). Of these, 66 per cent were female, while 33 per 
cent were male (DHET 2017, 10). For the same period, DHET $(2017,19)$ reported a graduation rate for distance education of 66.8 per cent (DHET 2017, 23). Clearly there is a discrepancy between student enrolment and student graduation in distance education. The question is how to support student success in South African distance higher education contexts so facilitate success.

Extant research highlights the significance of adult learner academic self-directedness in open-distance and e-learning (ODeL) contexts (Beach 2017, 61; Zhao and Chen 2016, 1). Nevertheless, many adult learners may not be fully equipped to practice self-directed learning (Zhao and Chen 2016, 2). Adult learner self-directedness is a nebulous concept but seems to comprise at least three broad components, namely: learning context; student autonomy and student behaviour. Student autonomy consists of student affect, study behaviours and metacognition (Song and Hill 2007, 27). Student affect is the range of emotions (positive or negative) experienced, and attitudes displayed by individual students (Song and Hill 2007, 32). Positive feelings in the education context may influence student outcomes positively (Rogaten and Moneta 2015, 225). Metacognition is an awareness of individual capacity to think clearly about learning and thought processes (Ozsoy, Memis, and Temur 2009, 155).

\section{BACKGROUND TO THE STUDY}

ODeL students should display a degree of academic self-directedness to facilitate success (Beach 2017, 61). The existing research on adult student self-directedness in ODeL contexts focus mainly on western and eastern universities (North America, Europe, Great Britain and China) and on measuring self-directedness for defined study fields (for example language learning and ICT) (Torenbeek, Jansen, and Suhre 2013, 1397; Wang et al. 2008, 18) or in the workplace (De Bruin and De Bruin 2011, 2). No reported research exists on measuring South African ODeL students' academic self-directedness (Botha 2014, 4.12). The factors that affect student success can be broadly clustered into three sets, namely: individual (personal characteristics, access to resources and so on); institutional (scholastic and clerical services) and external (socio-economic and political/regulatory) (Subotzky and Prinsloo 2011, 179). Although student autonomy in various guises forms part of the basket of student characteristics subjected to extensive research, the concept of adult learner self-directedness has been overlooked in the ODeL and African frameworks (Botha, Coetzee, and Coetzee 2015, 65).

Self-directed learners are described according to their intrinsic beliefs of autonomy, their autonomous behaviours or actions; or their evolution through cultivated autonomy to selfdirected learning (Cassidy 2011, 991; Knowles 1984, 12). Botha (2014, 2.44) describes adult learner self-directedness as the association between adult learners' displayed learning 
behaviours, partially in the learning context created by the higher education body, and partially by the student's inherent self-efficacy beliefs, motivational orientations and inspired learning activities (Coetzee and Botha 2013, 36). Research on adult learner self-directedness focuses on three broad categories, namely the learning environment; student cognition and affect; and learner behaviour (Botha 2014, 2.7; Song and Hill 2007, 27). Knowles (1984, 14-17) addressed the learning environment, indicating that adults learn best in a safe, non-threatening, inspiring environment focused on collaborative learning. Cassidy $(2011,992)$ explains a learning context balanced between demanding learning tasks and encouragement from the lecturer. Blashke $(2012,59)$ feels that situating the learning activities within the experience world of learners facilitates academic success. Social support from peers should be encouraged (Blashke 2012, 59; Feryok 2013, 2014; Furnborough 2012, 100). Furtak and Kunter (2012, 285) distinguish between procedural and cognitive support in the learning milieu. Self-directed students being active in the learning milieu is pivotal for successful learning.

The cognitive and affective aspects of learner self-directedness are based on students' motivational and cognitive orientations that inform their study behaviours. Knowles $(1984,9$ 10) believed that adult students should be treated as self-directed even when their behaviour indicates the opposite, since inherently all adults want their peers to acknowledge their capacity for self-directedness. Cassidy $(2011,994)$ supports the view that students' inherent motivational orientations and self-confidence are crucial in the cultivation of self-directedness but includes critical self-reflection on learning behaviours and achievements as part of self-directedness. Blashke $(2012,57)$ sees self-reflection as an essential component of heutagogy. Critical reflection on how one learns and on what is learnt, is vital for transformative learning theory (Mezirow 1997, 10). Mezirow $(1997,6)$ believes that it is the transformation that stems from individual critical reflection that eventually fosters self-directedness (Brown and Brown 2015, 137). Consequently, learners' active behavioural and cognitive engagement in the learning milieu and learning content contributes significantly to academic success (Cassidy 2011, 995).

Self-efficacy is highlighted by authors as an essential component of student autonomy, self-direction and academic success (Cassidy 2011, 995; Sumuer 2018, 31). Self-efficacy is individual beliefs of competence and capacity to achieve a set goal, given explicit personal application of energy (Cassidy 2011, 995; Sumuer 2018, 31). Students' cognitive and affective orientations determine their interactions with the study material and milieu; and become apparent in study behaviours that subsequently influence academic success (Cassidy 2011, 995).

In the South African context, beliefs of individual autonomy and self-efficacy may not indicate the kind of behaviours described above. Personal autonomy and learner control may 
be circumscribed by students' social-cultural learning experiences. According to Mezirow $(2000,6)$, individuals' socio-culturally formed frames of reference shape and define individual outlooks, insights, understanding and emotions, which in turn determine individual thought processes and behaviours. Du Toit-Brits $(2018,52)$ indicates that the complexity of the concept of adult learner academic self-directedness precludes the apparent belief that all adult students are essentially self-directed learners. On the other hand, Ellery and Baxen $(2015,93)$ indicate that student agency and reflective capacity are not acknowledged by academic teachers. Since students' identities as student are anchored in social structures, and these in turn are affected by power and access to resources (McKenna 2004, 273), the assumption of student agency in the defined sense may be a fallacy. Since ODeL higher education requires an established ability for self-directed learning context, further research on this topic in the South African context is vital.

Study behaviours are the deliberate observable actions and activities students exhibit, to achieve academic success (Botha 2014, 2.31). Study behaviours comprise, inter alia, learning styles; study effort; learning strategies; engagement in learning activities; participation in the learning context and study habits (Botha and Coetzee 2016, 247). Research supports the belief that learning context strongly influences student study behaviours and that careful attention should be given to designing learning contexts for student preferences and needs (Hattingh, Dison, and Woollacott 2019, 15). The need to devise learning milieus that foster learner academic self-directedness throughout the learning journey is a significant challenge for ODeL academics in tertiary education (Hewson 2018,4). The pressure to ameliorate student success significantly increases the challenge in the South African ODeL context, accentuating the need to ascertain students' self-directedness to inform learning milieu and learning material design (Hattingh et al. 2019, 15). The Adult Learner Self-Directedness Scale (ALSDS) was devised to encapsulate the four central elements of adult learner self-directedness, namely learning context, student cognition, and affect, and student study behaviours.

The ALSDS provides information on the factors comprising adult learner selfdirectedness in South African ODeL settings (Botha 2014, 2.26; Botha et al. 2015, 66). The four factors of adult learner academic self-directedness in ODeL are: (a) strategic utilisation of traditional officially provided resources; (b) engaged academic activity; (c) success orientation for open distance learning; and (d) academically motivated behaviour (Botha et al. 2015, 66). The four items were derived from Exploratory Factor Analysis (explained in the Research Methodology - data analysis section), and are described as follows (Botha et al. 2015, 66):

(a) Strategic utilisation of officially provided resources measures when and why self-directed learners use the academic resources offered by the tertiary education provider. 
(b) Engaged academic activity assesses the considered, significant study activities adult learners employ to develop subject-specific competence, and to progress in their academic endeavours.

(c) Success orientation for open distance learning measures adult learners' self-reported assurance that they can be successful ODeL students (self-efficacy beliefs).

(d) Academically motivated behaviour assesses the self-reported behaviour of adult learners that relates to motivational orientation in an ODeL milieu.

\section{RESEARCH METHODOLOGY}

\section{Data collection}

A quantitative survey design was used. The population of the study $(\mathrm{N}=438055)$ comprised undergraduate adult students in economic and management sciences at a comprehensive, ODeL South African university. A stratified, proportional, random sample of $n=10500$ was drawn, comprising diverse gender, race and age groups. The disproportionate representation of race and gender groups (71\% black Africans, $63 \%$ female) that comprised the demographics of the institution informed the choice of sampling method. Females comprised 62.7 per cent of the sample, while males comprised 37.2 per cent. Four race groupings were identified, namely: 86.3 per cent Black (African); 3.5 per cent Coloured; 2.7 per cent Indian and 7.4 per cent White. The age groups were clustered into five categories, namely: 18-25 (39.9\%); 26-30 (24.3\%); 31-40 (24.3\%); 41-50 (9.3\%) and over $50(1.6 \%)$.

The ALSDS is a self-reporting descriptively-anchored rating scale that takes approximately 20-30 minutes to complete. The desire to elicit responses from students to specific behaviours associated with effective self-directed tertiary education studies and the need to limit the number of questionnaire items to encourage participation in the survey indicated the use of a descriptively anchored scale (Botha 2014, 4.9). The descriptions on the questionnaire related to study behaviours linked with specific critical incidents during the tuition period in an ODeL university. A numerical value (from 1 to 5) was attached to the descriptions to provide for data capturing and analyses. Descriptive scales are regularly used to facilitate the participants' comprehension of scale items so as to improve the scale's usability and objectivity (Lubbe and Nitsche 2017, 44). Examples of the questions and labels follow:

1. How many hours per week do you devote to your studies at [the University]?

\begin{tabular}{|l|l|l|l|l|}
\hline 1 & 2 & 3 & 4 & 5 \\
\hline Less than one & One to two & Two to three & Three to four & More than four \\
\hline
\end{tabular}


7. When do you read your tutorial letters?

\begin{tabular}{|l|l|l|l|l|}
\hline 1 & 2 & 3 & 4 & 5 \\
\hline Never & $\begin{array}{l}\text { Before the } \\
\text { assignments are } \\
\text { due }\end{array}$ & $\begin{array}{l}\text { Before the } \\
\text { examination } \\
\text { date }\end{array}$ & $\begin{array}{l}\text { In the study time } \\
\text { allotted for that module }\end{array}$ & $\begin{array}{l}\text { As soon as I receive } \\
\text { them }\end{array}$ \\
\hline
\end{tabular}

11. What do you do when you experience a problem such as a family crisis or an unexpected heavy workload and you are not able to submit an assignment on time?

\begin{tabular}{|l|l|l|l|l|}
\hline 1 & 2 & 3 & 4 & 5 \\
\hline $\begin{array}{l}\text { I do not submit } \\
\text { the assignment }\end{array}$ & $\begin{array}{l}\text { Submit the } \\
\text { assignment late } \\
\text { and hope for the } \\
\text { best }\end{array}$ & $\begin{array}{l}\text { Contact the } \\
\text { lecturer on the } \\
\text { due date to } \\
\text { request an } \\
\text { extension }\end{array}$ & $\begin{array}{l}\text { Contact the lecturer } \\
\text { before the due date to } \\
\text { request an extension }\end{array}$ & $\begin{array}{l}\text { I never submit } \\
\text { assignments late } \\
\text { because I plan for } \\
\text { unexpected events } \\
\text { when I plan my study } \\
\text { time }\end{array}$ \\
\hline
\end{tabular}

22. What do you do when you struggle to understand the work?

\begin{tabular}{|l|l|l|l|l|}
\hline 1 & 2 & 3 & 4 & 5 \\
\hline $\begin{array}{l}\text { I become } \\
\text { discouraged and } \\
\text { stop working }\end{array}$ & $\begin{array}{l}\text { I contact a friend } \\
\text { for assistance }\end{array}$ & $\begin{array}{l}\text { I contact the } \\
\text { lecturer for } \\
\text { assistance }\end{array}$ & $\begin{array}{l}\text { I read through the } \\
\text { material again and, if I } \\
\text { still do not understand, } \\
\text { I contact the lecturer }\end{array}$ & $\begin{array}{l}\text { I never struggle to } \\
\text { understand the work }\end{array}$ \\
\hline
\end{tabular}

Source: The relationship between adult learner self-directedness and employability attributes - an open distance learning perspective (Botha 2014, table 4.6).

Figure 1: Examples of questions

The Post Office mailing system was used to distribute the questionnaires to the sample and receive back responses in stamped, self-addressed envelopes. On receipt of the responses, the data was coded and analysed. Respondents returned $n=1102$ usable questionnaires, indicating a response rate of 10.5 per cent.

A principal-axis factor analysis (PAFA) using direct, oblimin rotation with Kaiser normalisation established the factor structure of the ALSDS. The PAFA revealed the composite factors of the ALSDS and accounted for the maximum variance in the original set of variables. Due to the ample sample size $(n=1102)$, the factor loading for a significance level of .05 was set at .35, (Yang 2010, 481). Next, a two-phase exploratory factor analysis (EFA) was conducted. Respondents could give only one response to items 1 to 21 of the ALSDS but could potentially provide more than one response to items 22 to 35 , hence the two-phase EFA. In the event, most respondents provided only one response to the relevant items and the second responses were discarded because of too many "missing data" returns. For the sake of research rigour, a two-phase EFA was still conducted.

Finally, structural equation modelling (SEM) (Table 5 and Figure 2) was used to model the structural relationships between the latent variables. Structural relationships are complex, indicating both relationships and causality between latent variables. SEM is ustilised when regression analysis is unsuitable because of the dense interrelationships amongst the latent variables. 


\section{Data analysis}

The data for phase 1 of the EFA (items 1 to 21), yielded a Kaiser-Meyer-Olkin value of .83, exceeding the suggested lowest value of .60 (Hutcheson 2019, 9). The Bartlett's Test of Sphericity achieved statistical significance at $p<.001$, sustaining the factorability of the correlation matrix. Phase 2 of the EFA (items 22 to 35) produced a Kaiser-Meyer-Olkin value of .79, exceeding the suggested lowest value of .60 (Hutcheson 2019, 9), and the Bartlett's Test of Sphericity achieved statistical significance at $p<.001$, sustaining the factorability of the second correlation matrix. The results (Table 1) support the adequacy of the sample and indicate significant correlations between the variables.

Table 1: KMO and Bartlett's test: ALSDS

\begin{tabular}{|l|l|c|}
\hline \multicolumn{2}{|c|}{ EFA: PHASE 1: ITEMS 1 to 21 } \\
\hline Kaiser-Meyer-Olkin measure of sampling adequacy & .83 \\
\hline Bartlett's test of sphericity & Approximate chi-square & 3703.852 \\
\hline \multicolumn{2}{|c|}{ EFA: PHASE 2: ITEMS 22 to 35 } & 210 \\
\hline & Df & .000 \\
\hline Kaiser-Meyer-Olkin measure of sampling adequacy & .79 \\
\hline Bartlett's test of sphericity & Approximate chi-square & 1414.471 \\
\hline \multicolumn{2}{|c|}{91} \\
\hline & Df & .000 \\
\hline
\end{tabular}

Source: The relationship between adult learner self-directedness and employability attributes - an open distance learning perspective (Botha 2014, table 5.1).

The two-phase EFA yielded 4 factors - 3 factors from phase one, with eigenvalues exceeding 1.50 and 1 factor from phase 2, with eigenvalue exceeding 1.50. The factors obtained from phase one were named as follows: (1) strategic utilisation of officially provided resources; (2) engaged academic activity and (3) success orientation for open distance learning. The factor obtained from phase two was named academically motivated behaviour (factor 4). The ALSDS yielded acceptable internal consistency reliabilities of between .60 (strategic utilisation of officially provided resources) and .77 (success orientation for ODL) (Table 2). The ALSDS yielded a Cronbach alpha coefficient of .91 for the overall scale, thus being within the acceptable range according to Van Griethuijsen et al. $(2015,589)$. Adding more scale items to the factors with lower Cronbach alpha may increase the value (Van Griethuijsen et al. 2015, 589). For this initial study, the Cronbach alpha were regarded as acceptable. The four factors derived from the 2-phase EFA lead to the identification of the four factors associated with adult learner self-directedness in ODeL. 
Table 2: ALSDS: Internal Consistency Reliability Coefficients

\begin{tabular}{|l|l|c|c|}
\hline Factor & \multicolumn{1}{|c|}{ Name } & Cronbach's alpha & Number of items \\
\hline Factor 1 & Strategic utilisation of officially provided resources & .60 & 5 \\
\hline Factor 2 & Engaged academic activity & .60 & 5 \\
\hline Factor 3 & Success orientation for open distance learning & .77 & 11 \\
\hline Factor 4 & Academically motivated behaviour & .71 & 14 \\
\hline Overall scale & & .91 & 35 \\
\hline
\end{tabular}

Source: The relationship between adult learner self-directedness and employability attributes - an open distance learning perspective (Botha 2014, table 5.5).

The separate factors' Cronbach's alpha coefficients were acceptable for an exploratory study: Factors 1 (.60), 2 (.60) and 4 (.71). Factor 3 - Success orientation for ODeL (.77) and the overall scale (.91).

Descriptive statistical analysis (Table 3) examined the distribution of the scores. The four sub-scales' means vary from 2.68 to 3.75 . Strategic utilisation of officially provided resources produced the highest mean score, $(\mathrm{M}=4 ; \mathrm{SD}=.68)$, and Engaged academic activity produced the lowest mean score $(M=2.68 ; \mathrm{SD}=.65)$. Skewness for the four sub-scales varies from -.11 to -.73 , while the kurtosis varies from -.08 to -.51 .

Table 3: ALSDS: Means, Standard Deviations, Skewness and Kurtosis

\begin{tabular}{|l|c|c|c|c|}
\hline \multicolumn{1}{|c|}{ Construct } & Mean & $\begin{array}{c}\text { Std } \\
\text { deviation }\end{array}$ & Skewness & Kurtosis \\
\hline Strategic utilisation of officially provided resources & 3.96 & .69 & -.73 & -.19 \\
\hline Engaged academic activity & 2.68 & .65 & -.11 & -.51 \\
\hline Success orientation for open distance learning & 3.75 & .63 & -.38 & -.34 \\
\hline Academically motivated behaviour & 3.63 & .49 & -.43 & -.08 \\
\hline
\end{tabular}

Source: The relationship between adult learner self-directedness and employability attributes - an open distance learning perspective (Botha 2014, table 5.7).

Pearson product-moment correlation analysis with casewise deletion of missing data was performed. Pearson correlation analysis was acceptable for this early stage of analysis because of the sample size $(n=11020)$. Correlational analysis (Table 4$)$ indicated a positive correlation between the sub-scales of the ALSDS ( $\mathrm{r} \geq .08 \leq .41 ; p \leq .01)$, confirming the ALSDS' construct validity and indicating that each sub-scale measured an individual construct.

Table 4: Correlational Analysis: ALSDS Sub-Scales

\begin{tabular}{|l|c|c|c|c|c|}
\hline \multicolumn{2}{|c|}{} & \multicolumn{3}{c|}{ ALSDS } \\
\cline { 3 - 6 } & & $\begin{array}{c}\text { Strategic Utilisation } \\
\text { of officially } \\
\text { provided resources }\end{array}$ & $\begin{array}{c}\text { Success } \\
\text { Orientation for } \\
\text { ODeL }\end{array}$ & $\begin{array}{c}\text { Engaged } \\
\text { Academic } \\
\text { Activity }\end{array}$ & $\begin{array}{c}\text { Academically } \\
\text { Motivated } \\
\text { Behaviour }\end{array}$ \\
\hline $\begin{array}{l}\text { Strategic utilisation } \\
\text { of officially provided } \\
\text { resources }\end{array}$ & $r$ & 1 & & & \\
\hline $\begin{array}{l}\text { Success orientation } \\
\text { for ODeL }\end{array}$ & $\mathrm{r}$ & $.41^{* * *}$ & 1 & & \\
\hline
\end{tabular}




\begin{tabular}{|l|c|c|c|c|c|}
\hline \multicolumn{2}{|c|}{ ALSDS } & \multicolumn{4}{c|}{ ALSDS } \\
\cline { 3 - 6 } & $\begin{array}{c}\text { Strategic Utilisation } \\
\text { of officially } \\
\text { provided resources }\end{array}$ & $\begin{array}{c}\text { Success } \\
\text { Orientation for } \\
\text { ODeL }\end{array}$ & $\begin{array}{c}\text { Engaged } \\
\text { Academic } \\
\text { Activity }\end{array}$ & $\begin{array}{c}\text { Academically } \\
\text { Motivated } \\
\text { Behaviour }\end{array}$ \\
\hline $\begin{array}{l}\text { Engaged academic } \\
\text { activity }\end{array}$ & $\mathrm{r}$ & $.28^{* * *}$ & $.26^{* * *}$ & 1 & \\
\hline $\begin{array}{l}\text { Academically } \\
\text { motivated behaviour }\end{array}$ & $\mathrm{r}$ & $.17^{* * *}$ & $.29^{* * *}$ & $.09^{* * *}$ & 1 \\
\hline
\end{tabular}

Notes: $\mathrm{N}=1102 .{ }^{* * *} \mathrm{p} \leq 0.001$. Correlation values $\leq .29$ are practically significant (small effect). Correlation values $\geq .30 \leq .49$ are practically significant (medium effect). Correlation values $\geq .50$ are practically significant (large effect).

Source: The relationship between adult learner self-directedness and employability attributes - an open distance learning perspective (Botha 2014, table 5.9).

The SEM was conducted by modelling the data using AMOS 18 (Arbuckle 1995-2009, 103141), yielding a model indicating good fit.

Table 5: ALSDS Goodness-of-fit statistics: SEM

\begin{tabular}{|c|c|c|c|c|c|c|c|c|c|c|c|}
\hline Model & CMIN & df & CMIN/df & $\mathbf{p}$ & NFI & RFI & IFI & TLI & CFI & RMSEA & SRMR \\
\hline 1 & 275.17 & 53 & 5.19 & .000 & .95 & .95 & .97 & .96 & .97 & .065 & .034 \\
\hline
\end{tabular}

Note: $\mathrm{CMIN}\left(\mathrm{X}^{2}\right)=$ chi-square; $\mathrm{df}=$ degrees of freedom; $\mathrm{p}=$ significance level; $\mathrm{NFI}=$ Bentler-Bonett normed fit index; RFI = relative fit index; TLI = non-normed fit index; CFI = comparative fit index; RMSEA = root-meansquare error of approximation; SRMR = standardised root-mean-square residual.

Source: The relationship between adult learner self-directedness and employability attributes - an open distance learning perspective (Botha 2014, table 5.10).

Fit indices for SEM fall into three categories: goodness of fit, incremental fit and parsimonious fit. Goodness of fit assesses how well a statistical model explains covariance. Root Mean Square Error of Approximation (RMSEA) and standard root mean square residual (SRMR) are examples of goodness of fit indices. The RMSEA ranges from 0 to 1 . The smaller the RMSEA, the better the model fit. An RMSEA $\leq .06$ indicates acceptable model fit (Hu and Bentler 1999, 6). The SRMR ranges between 0 and 1; the closer to 0, the better the model fit. An SRMR of $\leq .05$ generally represents good model fit (Hu and Bentler 1999, 5). The RMSEA (.065) and SRMR (.034) represent acceptable model fit.

Incremental fit determines model fit by the degree to which the model explains the sample covariance relative to a more restricted null-model. The normed-fit index (NFI), incremental fit index (IFI) and comparative fit index (CFI) are examples of incremental fit indices. The NFI ranges between 0 and 1 , with NFI $\geq .95$ indicating good fit. The CFI ranges from 0 to 1 , and a $\mathrm{CFI} \geq 0.90$ indicates acceptable model fit (Hu and Bentler 1999, 6). The IFI ranges between 0 and 1; the closer IFI is to 1 , the better the model fit. The SEM model fit statistics NFI (.95), CFI (.97) and IFI (.97) all indicate good model fit.

$\operatorname{CMIN}\left(X^{2}\right)$ or chi-squared represents the amount of difference between expected and observed covariance matrices. Good model fit yields an insignificant result at the 0.05 threshold, because of an inverse relationship between sample size and chi-squared (Hayduk et al. 2006, 844). In the SEM, the CMIN/df(5.19) is acceptably small. 
The SEM illustrates standardised path coefficient estimates $(p=.000)$ amongst the adult learner self-directedness construct and related variables (Figure 2). The variance in the construct adult learner self-directedness is clarified extensively by the variable success orientation (.73), less by the strategic utilisation of officially provided resources variable $(.55)$ and the least by the variables engaged academic activity (.39) and academically motivated behaviour (.36).

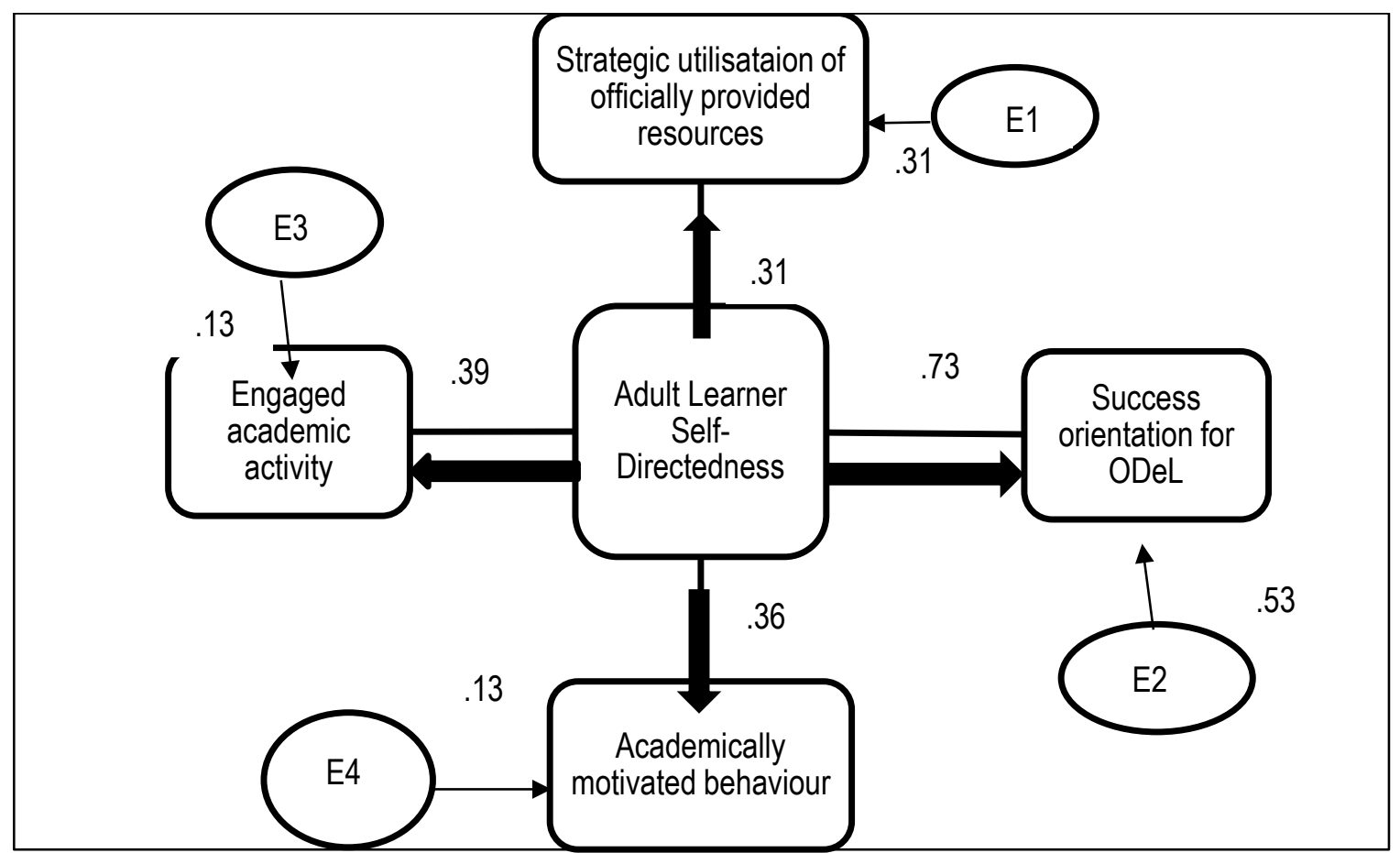

Note: all path coefficients significant at $p=.00$.

Figure 2: ALSDS Structural Equation Model (Source: The relationship between adult learner selfdirectedness and employability attributes - an open distance learning perspective (Botha 2014, figure 5.5).

\section{DISCUSSION}

Success orientation for open distance learning appears to be noteworthy when interpreting South African ODeL adult learner' self-directedness. The utilisation of the resources provided by the tertiary institution appears to be less significant. It seems that academic self-efficacy beliefs appear to strongly predict academic performance (Talsmaa et al. 2018, 144.), but is moderated by age. Healthy self-efficacy correlates positively with the acquisition of higherorder competencies such as complex reasoning ability (Olani et al. 2010, 526). The results indicate that students' well-developed and healthy beliefs in their ability to achieve success in ODeL contexts could influence their general self-directedness. The results evoke the story of "The little engine that could" (Sedelmaier 2012). The little engine, when requested to take a hefty load up a precipitous hill, willingly participates, indicating: "I think I can". Throughout 
the strenuous journey, the little engine tells itself "I think I can" and, on achieving success after a significant struggle, says: "I thought I could!" The little engine believed in its ability to achieve success, engaged actively in the task and was successful.

West and Meier $(2019,280)$ reports that self-efficacy and attitude significantly affect each other in student activity, but that learning material comprehension affect student attitude and self-efficacy. Li $(2012,145)$ reports that attitude and self-efficacy predict academic effort, but that effort does not directly influence academic achievement. Kahu and Nelson $(2018,59)$ indicate that student engagement is critical to academic success. Student engagement is influenced by four psycho-social constructs, namely academic self-efficacy (students' belief in their ability to achieve success in the academic tasks), student affect related to self-efficacy beliefs, connectedness to the institution, and well-being (influenced by anxiety and perceived lifeload) (Kahu and Nelson 2018, 64). Academic self-efficacy influences student learning behaviour, which affects engagement in learning tasks and eventual success (Kahu and Nelson 2018, 64). The apparent significance of success orientation for ODeL on student selfdirectedness should be understood within the framework of student engagement. In this context, the decreased apparent significance of engaged academic activity and academically motivated behaviour may indicate a skewed view of the significance of active engagement in academic work to achieve success held by ODeL students in this university. The results are in contradiction to those reported by Dison, Salom and Langsford (2019, 85), indicating that students employed resourcefulness to address various challenges experienced in the learning context. Resourcefulness is the affective, motivational fortitude associated with endurance in learning and associated with an internal resolve to learn, and thus associated with self-belief and learning behaviour.

The outcomes of in this research, though not definitive, highlight the need for further research into ODeL students' self-directedness, specifically student self-efficacy beliefs and active student engagement, to clarify how learning environments and materials should be designed to cultivate and nurture student self-belief, engagement and self-directedness. The results provide insights into the possible significance of success orientation for open distance learning and its relationship with South African ODeL adult learners self-directedness, and the apparent lack of significance of engaged student activity.

\section{LIMITATIONS AND CONCLUSIONS}

The demographic confines limit the generalisation of the results to the broader demographics. The sample consisted of South African ODeL adult students. Since only a small percentage of South Africans continue on to tertiary education, the results cannot be generalised to the broader 
community. The ALSDS focused on assessing self-directedness in ODeL consequently the results cannot currently be generalised to residential universities. The sample used in the study was limited to mainly black female adult students enrolled for studies in economic and management sciences, consequently the results cannot be applied to other work-related, gender and race contexts until further research is conducted. The limitations of the study provide fruitful grounds for further research in this field, both in the relevant university, in South Africa and in other African countries moving towards a broader adoption of ODeL.

Adult learner self-directedness is insufficiently researched in South Africa and the broader ODeL context. Since the findings indicate that adult learners in ODeL may realise the significance of self-belief (self-efficacy) in individual capacity to succeed in ODeL, but not necessarily the significance of translating those beliefs into fruitful learning behaviours by actively engaging with the learning context and learning material, the research may raise more questions than it answers. Aa indicated by previous research, self-belief only brings the student part of the way to academic autonomy. Agentic student action should follow on self-belief. Adult ODeL learners cannot only believe that they can - they should broach the steep hill, like the little engine did, to achieve their goals. Only then "I think I can" could translate into "I know I can" for adult learners in ODeL.

\section{REFERENCES}

Arbuckle, J. L. 1995-2009. Amos 18 user's guide. Amos Development Corporation.

Botha, Jo-Anne. 2014. "The relationship between adult learner self-directedness and employability attributes - an open distance learning perspective." Master's dissertation. Unisa. URL: http://hdl.handle.net/10500/13598.

Botha, J. and M. Coetzee. 2016. "The influence of biographical factors on adult learner self-directedness in an open distance learning environment." The International Review of Open and Distributed Learning 17(4): 242-263. DOI: https://doi.org/10.19173/irrodl.v17i4.2345.

Botha, J., M. Coetzee, and M. Coetzee. 2015. "Exploring adult learners' self-directedness in relation to their employability attributes in open distance learning." Journal of Psychology in Africa 25(1): $65-72$.

Beach, P. 2017. "Self-directed online learning: A theoretical model for understanding elementary teachers' online learning experiences." Teaching and Teacher Education 61(2017): 60-72. DOI: http://dx.doi.org/10.1016/j.tate.2016.10.007.

Blashke, L. M. 2012. "Heutagogy and lifelong learning: A Review of heutagogical practice and selfdetermined learning." The International Review of Research in Open and Distance Learning 13(1): $56-71$.

Brown, P. P. and C. S. Brown. 2015. "Transformative learning theory in gerontology: Nontraditional students.” Educational Gerontology 41(2): 136-148. DOI:10.1080/03601277.2014.950492.

Cassidy, S. 2011. "Self-regulated learning in higher education: Identifying key component processes." Studies in Higher Education 36(8): 989-1000. DOI:10.1080/03075079.2010.503269.

Coetzee, M. and J. Botha. 2013. "Undergraduate students' self-directedness in relation to their examination preparation styles in Open Distance Learning." Progressio 35(2): 34-57. 
De Bruin, K. and G. P. de Bruin. 2011. "Development of the Learner Self-Directedness in the Workplace Scale." S A Journal of Industrial Psychology / S A Tydskrif vir Bedryfsielkunde 37(1): 10 pages. DOI: $10.4102 /$ sajipv1.926.

Department of Higher Education and Training. 2017. Statistics on Post-School Education and Training in South Africa: 2017.

DHET see Department of Higher Education and Training.

Dison, L., Y. Salem, and D. Langsford. 2019. "Resourcefulness matters: student patterns for coping with structural and academic challenges." South African Journal of Higher Education 33(4): 76-93. DOI: $10.20853 / 33-4-2831$.

Du Toit-Brits, C. 2018. "Towards a transformative and holistic continuing self-directed learning theory." South African Journal of Higher Education 32(4): 51-65. DOI.org/10.20853/32-4-2434.

Ellery, K. and J. Baxen. 2015. "II always knew I would go to university”: A social realist account of student agency." South African Journal of Higher Education 29(1): 91-107.

Feryok, A. 2013. "Teaching for learner autonomy." Innovation in Language Learning and Teaching 7(3): 213-225. DOI: 10.1080/17501229.2013.836203.

Feryok, A. 2014. "Social-cultural theory and task-based language teaching: The role of praxis." ESOL Quarterly 51(3): 716-727. DOI: 10.1 002/tesq.390.

Furnborough, C. 2012. "Making the most of others: Autonomous interdependence in adult beginner distance language learners." Distance Education 33(1): 99-116. DOI: 10.1080/01587919. 2012.667962.

Furtak, E. M. and M. Kunter. 2012. "Effects of autonomy-supportive teaching on student learning and motivation." The Journal of Experimental Education 80(3): 284-316. DOI: 10.1080/00220973. 2011.573019.

Hattingh, T., L. Dison, and L. Woollacott. 2019. "Student learning behaviours around assessments." Australasian Journal of Engineering Education 24(1): 14-24. DOI: 10.1080/22054952. 2019.1570641.

Hayduk, L., G. Cummings, K. Boadu, H. Pazderka-Robinson, and S. Boulianne. 2006. “Testing! testing! one, two, three - Testing the theory in structural equation models!" Personality and Individual Differences 42(2007): 841-850. DOI: 10.1016/j.paid.2006.10.001.

Hu, L. and P. Bentler. 1999. "Cutoff criteria for fit indices in covariance structure analysis: Conventional criteria versus new alternatives." Structural Equation Modeling 6: 1-55.

Hutcheson, G. D. 2019. Principal Component Analysis: Sage Research Methods Foundations. Sage: London. DOI: http://dx.doi.org/10.4135/9781526421036.

Kahu, E. R. and K. Nelson. 2018. "Student engagement in the educational interface: Understanding the mechanisms of student success." Higher Education Research and Development 37(1): 58-71. DOI: 10.1080/07294360.2017.1344197.

Knowles, M. S. and Associates. 1984. Andragogy in Action. San Francisco: Jossey-Bass.

Lubbe, D. and A. Nitsche. 2019. "Reducing assimilation and contrast effects on selection interview ratings using behaviorally anchored rating scales." International Journal of Selection and Assessment 27(1): 43-53. DOI: 10.1111/ijsa.12230.

Li, L. K. Y. 2012. "A study of the attitude, self-efficacy, effort and academic achievement of CityU students towards research methods and statistics." Discovery - SS Student E-Journal 1: 154-183.

Mezirow, J. 1997. "Transformative learning: Theory to practice." New Directions for Adult and Continuing Education 1997(74): 5-12. DOI: 10.1002/ace.7401.

Mezirow, J. 2000. "Learning to think like an adult." In Learning as transformation: Critical perspectives on a theory in progress, ed. J. Mezirow, 3-34. San Francisco, CA: Jossey-Bass.

McKenna, S. 2004. "The interaction between academic literacies and student identities." South African Journal of Higher Education 18(3): 269-280. 
Olani, A., E. Harskamp, R. Hoekstra, and G. Van Der Werf. 2010. "The roles of self-efficacy and perceived teacher support in the acquisition of statistical reasoning abilities: A path analysis." Educational Research and Evaluation: An International Journal on Theory and Practice 16(6): 517-528. DOI: 10.1080/13803611.2011.554742.

Ozsoy, G., A. Memis, and T. Temur. 2009. "Metacognition, study habits and attitudes." International Electronic Journal of Elementary Education 2(1): 154-166.

Rogaten, J. and G. B. Moneta. 2015. "Use of creative cognition and positive affect in studying: Evidence of a reciprocal relationship." Creativity Research Journal 27(2): 225-231. DOI: 10.1080/ 10400419.2015.1030312.

Sedelmaier, J. J. 2012. "Watty Piper's 1930 'The Little Engine That Could'." www.printmag.com. (Accessed 3 March 2020).

Song, L. and J. R. Hill. 2007. "A conceptual model for understanding self-directed learning in online environments.” Journal of Interactive Online Learning 6(1): ISSN: 1541-4914.

Subotzky, G. and P. Prinsloo. 2011. "Turning the tide: A socio-critical model and framework for improving student success in open distance learning at the University of South Africa." Distance Education 32(2): 177-193.

Sumuer, E. 2018. "Factors related to college students' self-directed learning with technology." Australasian Journal of Educational Technology 34(4): 29-43.

Talsmaa, K., B. Schüz, R. Schwarzer, K. Norris. 2018. "I believe, therefore I achieve (and vice versa): A meta-analytic cross-lagged panel analysis of self-efficacy and academic performance." Learning and Individual Differences 61(2018): 136-150. DOI: 10.1016/j.lindif.2017.11.015.

Torenbeek, M., E. Jansen, and C. Suhre. 2013. "Predicting undergraduates' academic achievement: The role of the curriculum, time investment and self-regulated learning." Studies in Higher Education 38(9): 1393-1406. DOI:10.1080/03075079.2011.640996.

Van Broekhuizen, H., S. van der Berg, and H. Hofmeyr. 2016. "Higher education access and outcomes for the 2008 national Matric cohort." Stellenbosch Economic Working Papers, 16/16. A working paper of the Department of Economics and the Bureau for Economic Research at the University of Stellenbosch.

Van Griethuijsen, R. A. L. F., M. W. Van Eijck, H. Haste, P. J. Den Brok, N. C. Skinner, N. Mansou, A. S. Gencer, and S. BouJaoude. 2015. "Global patterns in students' views of science and interest in science." Research Science Education 2015(45): 581-603. DOI 10.1007/s11165-014-9438-6.

Wang, Y., H. Peng, R. Huang, Y. Hou, and J. Wang. 2008. "Characteristics of distance learners: Research on relationships of learning motivation, learning strategy, self-efficacy, attribution and learning results." Open Learning: The Journal of Open, Distance and e-Learning 23(1): 17-28.

West, J. and C. Meier. 2019. "Pre-service teachers' self-efficacy, attitudes and Academic performance with regard to undergraduate research modules." South African Journal of Higher Education 33(2): 268-283. DOI: $10.20853 / 33-2-2615$

Yang, H. 2010. "Factor Loadings.” In Encyclopedia of Research Design, ed. N. J. Salkind, 481-483. Thousand Oaks: Sage Publicatons. DOI: https://dx.doi.org/10.4135/9781412961288.

Zhao, H. and L. Chen. 2016. "How can self-regulated learning be supported in e-learning 2.0 environment: A comparative study." Journal of Educational Technology Development and Exchange 9(2): 1-20. 